\title{
Tannin, protein contents and fatty acid compositions of the seeds of several Vicia L. species from Turkey
}

\author{
By Kağan Kökten, ${ }^{\star *}$ Alpaslan Koçak, ${ }^{2}$ Eyüp Bağci, ${ }^{3}$ Mevlüt Akçura ${ }^{1}$ and Sait Çelik ${ }^{4}$
}

\author{
${ }^{1}$ Bingöl University, Faculty of Agriculture, Department of Field Crops, Bingöl, Turkey \\ ${ }^{2}$ Bingöl University, Faculty of Science and Arts, Department of Biology, Bingöl, Turkey \\ ${ }^{3}$ FIrat University, Faculty of Science and Arts, Department of Biology, Elazig, Turkey \\ ${ }^{4}$ Bingöl University, Faculty of Science and Arts, Department of Chemistry, Bingöl, Turkey \\ ( *Corresponding author: kahafe1974@yahoo.com)
}

\section{RESUMEN}

Taninos, contenido proteico y composición de ácidos grasos de semillas de algunas especies de Vicia $L$. de Turquía.

Las semillas oleaginosas de seis especies de Vicia (Leguninoas) fueron investigadas por su proteína, contenido en taninos y composición en ácidos grasos. El contenido de proteína en las semillas vario entre un $21.87 \%-31.33 \%$. El contenido de taninos en las semillas vario entre un $0.13 \%$ $1.07 \%$. La composición de ácidos grasos de estas seis diferentes especies fue determinada por GC mediante los esteres metílicos de sus ácidos grasos. Las semillas oleaginosas de las especies de Vicia contienen ácidos palmítico y esteárico como componentes mayoritarios entre los ácidos grasos saturados, con pequeñas cantidades de ácido mirístico, ácido palmitoleico y ácido margárico. Los ácidos grasos insaturados mayoritarios encontrados en las semillas oleaginosas fueron el ácido oleico, ácido linoleico y ácido linolénico. En este estudio, el contenido total de ácidos grasos saturado de las especies de Vicia vario entre 18.5 y $22.4 \%$ mientras que el de insaturados vario entre 71.1 y $80.3 \%$.

PALABRAS CLAVE: Ácidos grasos - Especies de Vicia - Proteína - Taninos.

\section{SUMMARY}

Tannin, protein contents and fatty acid compositions of the seeds of several Vicia L. species from Turkey.

The seedoils of six Vicia species (Leguminosae) were investigated for their protein, tannin contents and fatty acid compositions. The protein contents of the seeds were found to be between $21.87 \%-31.33 \%$. The tannin contents of the seeds were found to be between $0.13 \%-1.07 \%$. The fatty acid compositions of these six different species were determined by the GC of the methyl esters of their fatty acids. The oilseeds of Vicia species contain palmitic and stearic acids as the major component of their fatty acids, among the saturated acids, with small amounts of myristic, palmitoleic and margaric acids. The major unsaturated fatty acids found in the oilseeds were oleic, linoleic and linolenic acids. In this study, the total saturated fatty acids of Vicia species were between 18.5 and $22.4 \%$ while the total unsaturated fatty acids were between 71.1 and $80.3 \%$. species.

\section{INTRODUCTION}

The major use of vetches has been mixtures with cereals in hay, forage and green manure crops (Walton, 1992). The assumption being that this would allow for more immediate financial returns to the farming community without the necessity for an extra value-adding process involving livestock production, and would thus constitute an additional end-use option.

Polyunsaturated fatty acids (PUFAs) function as major nutrients, constituents of cell membranes and precursors of various signal molecules (Needleman et al., 1986, Sakuradani et al., 1999). They are important in both the medical and pharmaceutical fields, as they are involved in the human inflammatory response, blood-pressure regulation, cholesterol metabolism, and infant retinal and brain development (Horrobin, 1992; van Gool et al., 2003).

The need for protein in human and animal diets is increasing all over the world. Protein, especially for use in animal feed, is becoming more scarce and more expensive. This is particularly relevant as far as traditional protein sources are concerned, such as fish meal and meat and bone meal. Throughout the world today there is also a growing resistance against the use of animal protein sources in animal feeding (Brand, 2002). It is desirable, therefore, that the nutritional potential of alternative plant protein feeds, such as grain legumes is fully exploited (Brand et al., 2004).

The use of the Vicia species as grain legumes requires an understanding of their nutritive value and the potential toxicity of the grain of the different species to the various types of livestock (fish, poultry, pigeons, pigs, horses, cattle, sheep, goats) and humans (Enneking, 1995). The presence of tannins, saponins, phytic acid and other antinutritional substances hinder their use for human consumption (Morrow, 1991). Tannins affect the availability of amino acids and the utilization of protein while they inhibit the activities of digestive enzymes (Griffiths and Mosely, 1980; Sharma and Sehgal, 1992; ChiFai et al., 1997). 
The widespread use of legumes makes this food group an important source of lipid and fatty acids in animal and human nutrition. Some reports dealing with the total lipid and fatty acid compositions were published by a few researchers (Welch and Griffiths, 1984; Grela and Gunter, 1995; Akpinar et al., 2001; Bakoglu et al., 2009; Pastor-Cavada et al., 2009b; Yoshida et al., 2009).

The objective of the present study was to determine the tannin and protein contents of the seeds of several Vicia L. species ( $V$. angustifolia Reichard., V. peregrina L., V. narbonensis L., $V$. hybrida L., V. ervilia (L.) Willd. and V. cracca L. subsp. cracca), to characterize seed fatty acids used by animals in field, to establish the nutritional value and to make contributions as renewable resources of FA and other chemical patterns in these crops.

\section{MATERIAL AND METHODS}

\subsection{Seed samples}

The Vicia species used in this study were $V$. angustifolia Reichard., V. peregrina L., V. narbonensis L., V. hybrida L., V. ervilia (L.) Willd. and V. cracca L. subsp. cracca. Mature seeds of these species were collected from various locations in the Adana province of Turkey between June and August 2009.

\subsection{Oil extraction and preparation of fatty acid methyl esters (FAME)}

Impurities were removed from the seeds and the clean seeds were ground into powder using a ball mill. Lipids were extracted with hexane/isopropanol 2v/v (Hara and Radin, 1978). The lipid extracts were centrifuged at $10.0 \mathrm{~g}$ for $5 \mathrm{~min}$ and filtered; then the solvent was removed on a rotary evaporator at $40^{\circ} \mathrm{C}$.

\subsection{Capillary GLC}

Fatty acids in the lipid extracts were converted into methyl esters by means of $2 \%$ sulphuric acid $(\mathrm{v} / \mathrm{v})$ in methanol (Christie, 1990). The fatty acid methyl esters were extracted with hexane. Then the methyl esters were separated and quantified by gas chromatography and flame ionization detection (Schimadzu GC, 17 Ver.3) coupled to a glass GC 10 software computing recorder. Chromatography was performed with a capillary column (25 m in length) and $0.25 \mathrm{~mm}$ in diameter, Permabound 25, Machery, Nagel, Germany, using nitrogen as carrier gas (flow rate $0.8 \mathrm{ml} / \mathrm{min}$ ). The temperatures of the column, detector and injector valve were $130-220$ and $240-280^{\circ} \mathrm{C}$, respectively. Identification of the individual method was performed by frequent comparison with authentic standard mixtures that were analyzed under the same conditions.

\subsection{Determination of protein and tannin contents}

Seed samples were cleaned and protein content was analyzed according to the method of AOAC
(1990). The tannin contents of the seeds were determined by the method of Makkar et al. (1995). Protein and tannin analyses were carried out in triplicate.

\subsection{Statistical Analysis}

The experimental design was a completely randomized design with 3 replications. Data were analyzed using the SAS packet program.

\section{RESULTS AND DISCUSSION}

In this study, the total protein, fatty acid composition and tannin contents of several Vicia species from Turkey were determined. The results of the fatty acid analysis are shown in Table 1 and Figure 1, and the total protein and tannin contents are shown in Table 2.

The fatty acid composition of these plants used as feed crops from the Fabaceae family showed different saturated and unsaturated fatty acid concentrations. The main components in the oilseed of feed crops were linoleic, linolenic, oleic and palmitic acid. In all Vicia species studied, linoleic acid was found to be the major component (43.65\%-63.84\%). The oleic acid content was at its highest level in $V$. narborensis $(29.87 \%)$, but found to be a its lowest in V. ervilia $(9.20 \%)$ and V. cracca subsp. cracca $(7.70 \%)$. Linoleic acid was found in the greatest proportion in the seed oil. The linoleic acid content was at its highest level in $V$. cracca subsp. cracca $(63.84 \%)$, but found to be at its lowest level in $V$. hybrida (43.65\%). The oilseeds of all the species were richer in linoleic than linolenic acid. The linolenic acid content was the highest in V. hybrida $(21.98 \%)$ and $V$. ervilia $(19.69 \%)$. Linolenic acid was also detected at a low level in $V$. narborensis (3.98\%) (Table 1). Linoleic acid is needed for a normal immune response and in essential fatty acids, a deficiency impairs B and T cell mediated responses (Meydani et al., 1991). The linoleic acid contents of the Vicia species has shown the greatest differences among the species studied. It is reported that, the oilseeds Vicia species also have large amounts of oleic (14.6$35.0 \%)$, linoleic (4.33-9.42\%), and linolenic acid (1.95-9.20\%) (Akpinar et al., 2001).

We have used the biplot (Figure 1) to compare Vicia species on the basis of fatty acid compositions and to identify species or groups of Vicia that are particularly good in certain aspects (Rubio et al., 2004). Specifically, the comparison between $V$. angustifolia and $V$. narbonensis indicates that $V$. angustifolia was better in palmitic acid, whereas $V$. narbonensis was better in arachidic, myristic, palmitoleic, oleic acid and lignoceric acid. Similarly, $V$. hybrida and $V$. ervilia had a greater value than $V$. angustifolia, $V$. peregrina and $V$. cracca subsp. cracca in all fatty acid compositions except palmitic acid and linoleic acid. The interpretation of the biplot also shows that $V$. peregrina and $V$. cracca 
Table 1

Fatty acid composition of some Vicia species from Turkey

\begin{tabular}{|c|c|c|c|c|c|c|c|c|c|c|c|c|c|}
\hline \multirow[b]{2}{*}{ Vicia species } & \multicolumn{13}{|c|}{ Fatty Acid Components } \\
\hline & 14:0 & $16: 0$ & $\begin{array}{c}16: 1 \\
\Delta 9\end{array}$ & 17:0 & 18:0 & $\begin{array}{c}18: 1 \\
\Delta 9\end{array}$ & $\begin{array}{c}18: 2 \\
\Delta 9,12\end{array}$ & $\begin{array}{c}18: 3 \\
\Delta 9,12,15\end{array}$ & 20:0 & 22:0 & $24: 0$ & TSFA & TUSFA \\
\hline V. angustifolia Reichard. & -- & 17.77 & -- & -- & 3.84 & 15.82 & 53.19 & 8.57 & 0.81 & -- & -- & 22.4 & 77,6 \\
\hline V. peregrina $\mathrm{L}$. & -- & 13.87 & -- & -- & 4.20 & 12.44 & 62.08 & 7.40 & 0.10 & -- & -- & 18.0 & 81.9 \\
\hline V. narbonensis L. & 1.04 & 14.45 & 1.76 & -- & 1.95 & 29.87 & 44.49 & 3.98 & 1.02 & -- & 1.43 & 19.9 & 80.1 \\
\hline V. hybrida L. & 0.26 & 11.2 & 0.24 & 0.27 & 5.80 & 12.63 & 43.65 & 21.98 & 1.31 & 0.53 & 0.25 & 19.6 & 78.5 \\
\hline V. ervilia (L.) Willd. & -- & 10.33 & 0.40 & 0.26 & 5.0 & 9.20 & 53.77 & 19.69 & 0.51 & 0.27 & -- & 16,4 & 83.1 \\
\hline V. cracca L. subsp. cracca & -- & 14.9 & 0.23 & -- & 2.36 & 7.70 & 63.84 & 8.50 & 0.28 & 0.71 & 0.40 & 18.7 & 80.3 \\
\hline
\end{tabular}

14:0: myristic acid, 16:0: palmitic acid, 16:1 $\Delta 9$ : palmitoleic acid, 17:0: margaric acid, 18:0: stearic acid, 18:1 $\Delta 9$ : oleic acid, 18:2 $\Delta 9,12$ : linoleic acid, 18:3 $\Delta 9,12$, 15: linolenic acid, 20:0: arachidic acid, 22:0: behenic acid, 24:0: lignoceric acid, TSFA: Total saturated fatty acid, TUSFA: Total unsaturated fatty acid

Table 2

Total protein (\%) and tannin contents (\%) of some Vicia species from Turkey

\begin{tabular}{lcc}
\hline Vicia Species & Protein & Tannin \\
\hline V. angustifolia Reichard. & $29,07 \mathrm{~b}$ & $0,90 \mathrm{ab}$ \\
V. peregrina L. & $29,30 \mathrm{~b}$ & $0,67 \mathrm{~cd}$ \\
V. narbonensis L. & $24,10 \mathrm{~d}$ & $0,83 \mathrm{bc}$ \\
V. hybrida L. & $27,07 \mathrm{c}$ & $1,07 \mathrm{a}$ \\
V. ervilia (L.) Willd. & $21,87 \mathrm{e}$ & $0,13 \mathrm{e}$ \\
V. cracca L. subsp. cracca & $31,33 \mathrm{a}$ & $0,47 \mathrm{~d}$ \\
LSD & 1,6772 & 0,22 \\
\hline
\end{tabular}

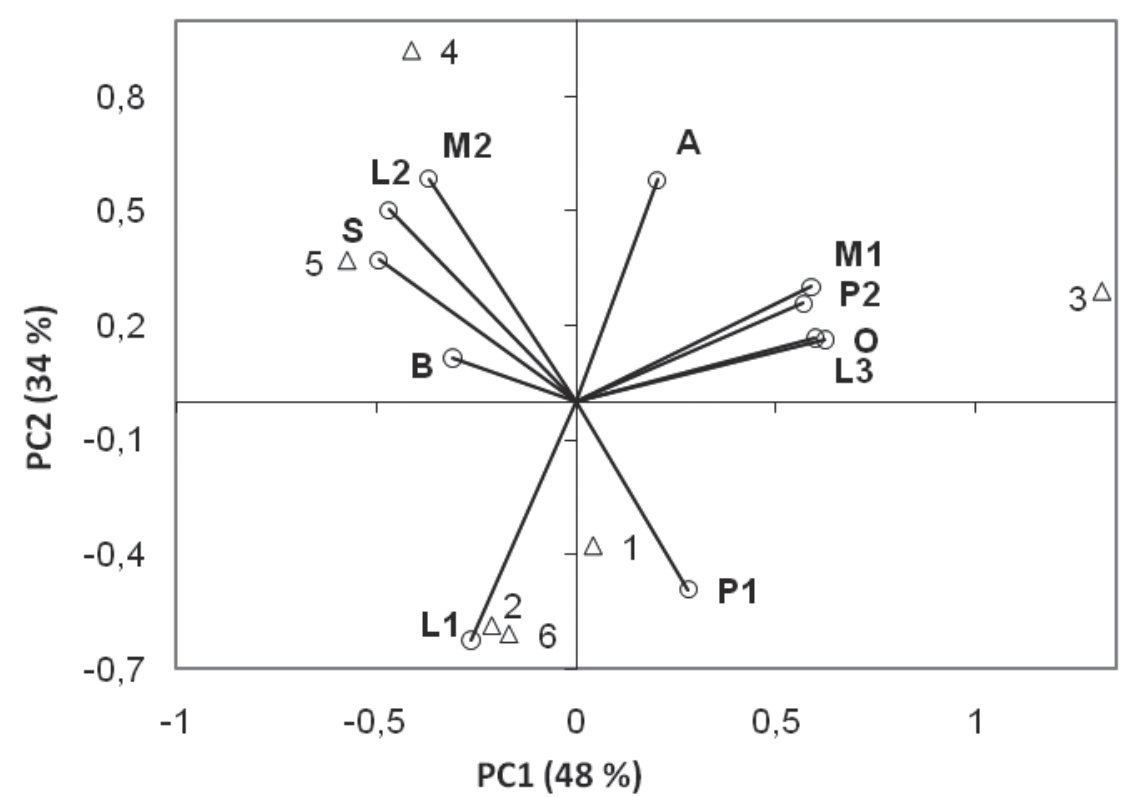

Figure 1.

The biplot of 6 Vicia species for fatty acid composition. (Vicia species: $1: V$. angustifolia, 2: $V$. peregrina, 3: $V$. narbonensis, 4: $V$. hybrida, 5: $V$. ervilia, 6: $V$. cracca subsp. Cracca. Fatty acids: M1:myristic acid, P1: palmitic acid, P2: palmitoleic acid, M2: margaric acid, S: stearic acid, O: oleic acid, L1: linoleic acid, L2: linolenic acid, A: arachidic acid, B: behenic acid, L3: lignoceric acid. 
subsp. cracca were the highest in linoleic acid while $V$. angustifolia was the highest in palmitic acid. $V$. narbonensis had the highest levels of myristic acid, palmitoleic acid, oleic acid and lignoceric acid. $V$. hybrida had the highest contents of margaric, linolenic and stearic acids (Figure 1).

The total saturated fatty acids (TSFA) of the Vicia species were between 18 and $22.4 \%$. Vicia peregrina had the lowest level of saturated acid and $V$. angustifolia had the highest amount of saturated fatty acid (SFA) concentration (Table 1). On the other hand, the unsaturated fatty acid composition of the Vicia species was determined at levels as high as those reported for other family members of the Vicia species (Pastor-Cavada et al., 2009a), Fabaceae (Bagci et al., 2004a), Lamiaceae (Bagci, 2007), Boraginaceae (Bagci et al., 2004b), Apiaceae (Bena et al., 1998) family patterns. Vicia ervilia had the highest level of unsaturated fatty acid (83.1\%), along with $V$. paregrina $(81.9 \%)$, V. cracca subsp. cracca $(80.3 \%)$, V. narborensis $(80.1 \%), V$. hybrida $(78.5 \%), V$. angustifolia $(77.6 \%)$, respectively. Vicia ervilia and Onobrychis fallax (Fabaceae) had 80.43 and $79.58 \%$ unsaturated fatty acid concentrations in their oilseeds (Bakoglu et al., 2009).

The results showed that the genera of the Fabaceae genus patterns have qualitatively and quantitatively different fatty acids, particularly unsaturated fatty acid contents. But some results showed that the linoleic-palmitic type of fatty acid is typical for some genera patterns like Cassia nodosa, Berlinia auriculata, Bauhinia monandra, Parkia clappertonina (Balogun and Fetuga, 1985), some Astragalus (Bagci, 2006) and Ebenus species (Azcan et al., 2001) or the linoleic-oleic-palmitic type, like in the Lathyrus species (Bagci and Sahin, 2004) and some Crolataria species (Fabaceae). But some genera patterns showed the same quantity of linoleic acid and linolenic acid components in their oilseeds, like the Vicia species studied in this work, several Astragalus species (Bagci, 2006).

The total protein of the different grain legumes is presented in Table 2. V. cracca subsp. cracca had the highest protein content and differed significantly $(P \leq 0.05)$ from the others. The total protein amounts of the Vicia species studied were between 21.87- 31.33\% in Vicia ervilia and Vicia cracca subsp. cracca and 24.10, 27.07, 29.07 and $29.30 \%$ in $V$. narbonensis, $V$. hybrida, $V$. angustifolia and $V$. peregrina . The Crude Protein (CP) content of narbon beans ( $V$. narbonensis) may vary between 26.0 and $32.0 \%$ (Abd El Moneim, 1992). These values were higher than the values found in the present study. Brand et al. (2004) found the CP level of narbon beans to be $23.7 \%$ and Bakoglu et al. (2009) found the CP level bitter vetch to be $20.09 \%$. These values were slightly lower than the values found in the present study.

The tannin contents of the different grain legumes belonging to the Vicia genus are presented in Table 2. $V$. hybrida had the highest tannin and differed significantly $(P \leq 0.05)$ from the others. The tannin amounts of the feed crops studied were between
$0.13-1.07 \%$ in Vicia ervilia and Vicia hybrida and 0.47 , $0.67,0.83$ and $0.90 \%$ in $V$. cracca subsp. cracca, $V$. peregrina, $V$. narbonensis and $V$. angustifolia respectively. It was reported that condensed tannin may act as an antihelmintic against parasitic nematodes or indirectly by improving the nitrogen supply (Niezen et al., 1995; Robertson et al., 1995; Butter et al., 1998).

The consequences of the complexes between tannin and protein (protein bound) or carbohydrate (fiber bound) and decreased digestibility are that the microbial population is denied access to essential amino acids and decreased $\mathrm{N}$ availability which may lead to restricted growth and depressed fermentative activity (Longland et al., 1995).

\section{CONCLUSION}

The oil contents of the studied legumes belonging to the Vicia genus showed quantitative differences but the oilseeds showed uniform fatty acid composition. The legumes are rich in proteins and complex carbohydrates and are an important source of minerals and vitamins (Mahadewamma and Tharanathan, 2004). The results revealed that the oilseeds of the Vicia species studied with a substantial amount of very long chain fatty acids might have attracted attention because of their value for nutritional, industrial and renewable resources.

\section{REFERENCES}

Abd El Moneim AM. 1992. Narbon vetch (Vicia narbonesis $L$ ): A potential feed legume crop for dry areas in western Asia. J. Agron. Crop. Sci. 169, 347-355.

Akpinar N, Akpinar MA, Türkoğlu Ș. 2001. Total lipid content and fatty acid composition of seeds of some Vicia L. species. Food Chemistry 74, 449-453.

AOAC. 1990. Official Method of Analysis. 15th. edn. Association of Official Analytical Chemist, Washington, DC. USA.

Azcan N, Saricoban S, Demirci B, Aytac Z, Baser KHC. 2001. Oilseed of fifteen Ebenus taxa growing in Turkey. Chem. Nat. Comp. 37, 3, 253-255.

Bagci E, Sahin A. 2004. Fatty acid patterns of the oilseed of some Lathyrus species L. (Papilionideae) from Turkey, a chemotaxonomic approach. Pakistan J. Botany 36, 2, 403-413.

Bagci E, Bruehl L, Özçelik H, Aitzetmuller K, Vural M, Sahim A. 2004. A study of the fatty acid and tocochromanol patterns of some Fabaceae (Leguminosae) plants from Turkey. Grasas y Aceites 55, 4, 378-384.

Bagci E, Bruehl L, Aizetmuller K, Altan Y. 2004. Fatty acid and tocochromanol patterns of some Turkish Boraginaceae - a chemotaxonomic approach. Nordic J. Botany. 22, 6, 719-726.

Bagci E. 2006. Fatty acid composition of some Astragalus species from Turkey. Chem. Nat. Comp. 42, 6, 645648

Bagci E. 2007. Fatty acids and tocochromanol patterns of some Turkish Apiaceae (Umbelliferae) plants; a chemotaxonomic approach. Acta Botanica Gallica $154,2,143-151$. 
Bakoglu A, Bagci E, Ciftci H. 2009. Fatty acid, protein contents and composition of some feed crops from Turkey. Journal of Food Agriculture and Environment 7, 343-346.

Balogun AM, Fetuga BL. 1985. Fatty acid composition of oilseed of some members of the leguminosae family. Food Chem. 17, 3, 175-182.

Bena G, Prosperi JM, Lejeune B, Olivieri I. 1998. Evolution of annual species of the genus Medicago: A molecular phylogenetic approach. Molecul. Phisiogen. Evol. 9, 3, 552-559.

Brand TS. 2002. A review on research performed in the Mediterranean rainfall area of South Africa on alternative plant protein sources in pig diets. Pig News and Inf. 23, 9-15.

Brand TS, Brand DA, Cruywagen CW. 2004. Chemical composition, true metabolisable energy content and amino acid availability of grain legumes for poultry. South African J. Animal Sci. 34, 116-122.

Butter NL, Dawson JM, Wakelin D, Buttery PJ. 1998. Effect of dietary tannin and protein level on the susceptibility of sheep to parasitic infection. Proceeding of British Society of Animal Science p.97.

Chi-Fai C, Peter CKC, Yum-Shing W. 1997. Effect of cooking on content of amino acids and antinutrients in the chinese indigenous legume seed. J. Sci. Food Agric. 75, 447-452.

Christie WW. 1990. Gas Chromatography and Lipids: A Practical Guide. The Oily Press, Ayr, 307 pp.

Enneking D. 1995. The toxicity of Vicia species and their utilisation as grain legumes. 2nd edition. Centre for Legumes in Mediterranean Agriculture (CLIMA). Occassional Publication No:6. 134 pp. ISSN 1320 3665, ISBN 0864224176.

Grela ER, Gunter KD. 1995. Fatty acid composition and tocopherol content of some legume seeds. Animal Feed Science and Technology 52, 325-331.

Griffiths DW, Mosely G. 1980. The effect of diet containing field beans of high and low polyphenolic content on the activity of digestive enzymes in the intestines of rats. $J$. Sci. Food Agic. 31, 255-259.

Hara A, Radin NS. 1978. Lipid extraction of tissues with a low- toxicity solvent. Anal. Biochem. 90,1, 420-436.

Horrobin DF. 1992. Nutritional and medical importance of gamma-linolenic acid. Prog. Lipid Res. 31,2, 163-194.

Longland AC, Theodorou MK, Sanderson R, Lister SJ, Powell CJ, Morris P. 1995. Non-starch polysaccharide composition and in vitro fermentability of tropical forage legumes varying in phenolic content. Animal Feed Science and Technology 52,161-177.

Mahadewamma S, Taharanathan T. 2004. Processing of legumes. Resistant starch and dietary fiber contents. J. Food Qualty 27, 289-303.

Makkar HPS, Blümmel M, Becker K. 1995. Formation of complexes between polyvinylpolypyrrolidone or polyethylene glycols and tannins and their implication in gas production and true digestibility in vitro techniques. British Journal of Nutrition 73, 897-913

Meydani M, Seitz HK, Blumberg B, Russell RM. 1991. Effect of Chronic Ethanol Feeding on Hepatic and
Extrahepatic Distribution of Vitamin E in Rats. Alcohol. Clinic. Experiment. Res. 15, 5, 771-774.

Morrow B. 1991. The rebirth of legumes. Food Technol. 45, 96-121.

Needleman P, Turk J, Jakschik BA, Morrison AR, Lefkowith JB. 1986. Arachidanic acid metabolism. Annu. Rev. Biochem. 55, 69-102.

Niezen JH, Waghorn GC, Charleston WAG, Waghorn GC. 1995. Growth and gastrointestinal nematode parasitism in lambs grazing either Lucerne or sulla which contains condensed tannin. Journal of Agricultural Science (Cambridge) 12, 281-289.

Pastor-Cavada E, Juan R, Pastor JE, Alaiz M and Vioque J. 2009a. Fatty Acid Distribution in the Seed Flour of Wild Vicia Species from Southern Spain. Journal of the American Oil Chemists' Society 86, 977-983.

Pastor-Cavada E, Juan R, Pastor JE, Alaiz M, Vioque J. 2009b. Chemical Composition and Nutritional Characteristics of the Seed Oil of Wild Lathyrus, Lens and Pisum Species from Southern Spain. Journal of the American Oil Chemists' Society 86, 329-335.

Robertson HA, Niezen JH, Waghorn GC, Charleston WAG, Jinlog M. 1995. The effect of six herbage on live weigh gain, wool growth and feacel egg count of parasited ewe lamb. Proceedings of New Zealand Society of Animal Production 55,199-201.

Rubio J, Cubero JI, Martín LM, Suso MJ, Flores F. 2004. Biplot analysis of trait relations of white lupin in Spain. Euphytica 135, 217-224.

Sakuradani E, Kobayashi M, Ashikari T, Shimizua T. 1999. Identification of Delta 12-fatty acid desaturase from arachidonic acid-producing Mortierella fungus by heterologous expression in the yeast Saccharomyces cerevisiae and the fungus Aspergillus oryzae. Eur. J. Biochem. 261, 3, 812-820.

Sharma A, Sehgal S. 1992. Effect of domestic processing, cooking and germination on the trypsin inhibitor and tannin contents of faba bean (Vicia faba). Plant Food Hum. Nutr. 42, 127-133.

Van Gool CJ, Thijs C, Henquet CJM, van Houwelingen AC, Dagnelie PC, Schrander J, Menheere RP, van den Brandt PA. 2003. gamma-Linolenic acid supplementation for prophylaxis of atopic dermatitis - a randomized controlled trial in infants at high familial risk. American J. Clin. Nutr. 77, 4, 943-951.

Walton BB. 1992. Beyond corporate culture. Fortune 126, 10, 38.

Welch RW, Griffiths DW. 1984. Variation in the oil content and fatty acid composition of field beans (Vicia faba) and peas (Pisum spp.). Journal of the Science of Food and Agriculture 35, 1282-1289.

Yoshida H, Saiki M, Yoshida N, Tomiyama Y, Mizushina Y. 2009. Fatty acid distribution in triacylglycerols and phospholipids of broad beans (Vicia faba). Food Chemistry 112, 924-928. 